\title{
Adopting a Learner-Centered Methodology at Sultan Qaboos
}

\section{University}

\author{
Salma Al-Humaidi ${ }^{{ }^{*}}$
}

${ }^{1}$ Sultan Qaboos University, Muscat, Oman

*Salma Al-Humaidi, E-mail: shumaidi@squ.edu.om

\begin{abstract}
Sultan Qaboos University implemented a project for adopting a learner-centered methodology in the preparation program of the teacher-trainees of English at the College of Education. The learning materials package used in the project was developed as a result of the collaboration of two parities: Sultan Qaboos University and the American Partnership Initiative represented by Seward Incorporated. In the package, two independent variables have been manipulated: (1) the principles of the learner-centered method and the e-learning Moodle platform. The purpose of this study is to investigate the effectiveness of this project. To this end, two research tools (an achievement test and a student attitudinal feedback form) were developed, validated and applied to 150 ELT student teachers divided into four experimental groups and three control groups. The students in the experimental groups cover the developed package whereas those in the control groups cover the same topics in the package adopting the traditional method, (i.e. lecturing and face-to-face teaching). Preliminary indicators and views of the participants (faculty and students) show that the project is effective and successful for more than one reason: (1) involving students in active learning processes and tasks, (2) minimizing the use of lectures as the principle mode of instruction, (3) giving students increased ownership of their learning, (4) fostering team work and cooperative learning, and (5) manipulating technology and e-learning efficiently. Numerating these benefits, however, does not mean the absence of problems to do with the quantity of the readings and assignments, use of technology, and the nature of the tasks accompanying the topics.
\end{abstract}

\section{Keywords}

learner-centered methodology, pre-service teacher education, effectiveness, achievement

\section{Learner-Centered Method}

The principles of the student centered methodology originated in the school of constructivism, which opposes the practices associated with the teacher-as-expert approach knowledge (Bransford, Brown, \& Cocking, 1999; Garfield, 1995; Duckworth, 1987; Piaget \& Inhelder, 1969; Piaget, 1973; Vygotsky, 1978 as cited in Sablonnière; Taylor \& Sadykova, 2009). Piaget's core idea was that children are active thinkers, constantly trying to construct a more advanced understanding of their world. He focused on the 
development of logical or systematic concepts through social exchange in which children are actively and individually constructing their own social knowledge, rather than merely copying. Constructivist learning theory was considered a basis for the development of student-centered methods (Hannafin, Hill, \& Land, 1997), which were described by Cannon and Newble (2000, pp. 16-17) as "ways of thinking about teaching and learning that emphasize student responsibility and activity in learning rather than content or what the teachers are doing".

Due to the influence of constructivist learning theory, a plethora of new teaching methods arose which defined learning as an "active process in which learners are active sense makers who seek to build coherent and organized knowledge" (Mayer, 2004, p. 14, cited in Baeten, Kyndt, Struyven, \& Dochy, 2010). Consequently, some teaching methods/approaches that reflect the characteristics of student-centered learning were developed that indeed emphasized students' behavioral activity during learning. Examples of these teaching methods are: active learning, collaborative/cooperative learning, team-based learning, student-activating teaching methods, problem-based learning, powerful learning environments, minimal guidance approach, discovery learning, open-ended learning environments, project-based learning, and case-based learning (Bowel \& Eison, 1991; Mayer, 2004 cited in Baeten; Kyndt, Struyven, \& Dochy, 2010). Those methods that emphasize students' activities are often presented as the pedagogical opposite of traditional lectures where the teacher provides information that is passively received by the students (Prince, 2004).

Research shows that there are crucial factors that should be considered while attempting to implement and evaluate student-centered methods, as these will determine the positive or negative effects of such methods. Some of these factors are: learners' perceptions, attitudes and their characteristics, length of time needed, the appropriate instruments to be used, how student centered methods are to be implemented, teacher professional capacity, available resources, cultural factors and learner background (Ahmed \& Mahmood, 2010; Sablonniere, Taylor, \& Sadykova, 2009; Vavrus, 2009; Gravoso et al., 2008; Schuh, 2004; O’Sullivan, 2003).

Research has provided evidence of the usefulness of learner-centered methodology on students' learning. Geisli (2009) conducted a study to determine the effect of student-centered training methods on student success. A pre-post test experimental design was used with a control and an experimental group. The tool for data collection was an achievement test developed by the researcher. The results showed that the success was significantly higher in the group where student centered methods were applied compared to the teacher centered group.

Another study that showed a significant difference in student achievement is that of Ahmed and Mahmood (2010). They investigated the effects of three experimental learning conditions on prospective teachers' learning experience and achievement in an Educational Psychology course. These conditions include a traditional instruction model and two cooperative learning models. The subjects of the study were thirty-two student teachers enrolled in a Master's degree program.

The results revealed that there was a statistically significant difference between prospective teachers' 
scores on learning experience measure across the three experimental conditions. The results also revealed that there was a statistically significant difference in achievement scores favoring both cooperative learning conditions. It was reported that cooperative learning enhances perspective teachers' academic achievement as compared to traditional instruction. It also promoted enriched, enjoyable and interactive learning experiences. In addition to achievement, this study also provided evidence on the effect of learner-centered methodology in the form of cooperative learning models on quality learning which is a focus of the studies described below.

Sivan, Leung, Woon and Kember (2000) examined the effectiveness of active learning through the use of several learning activities implemented in two undergraduate programs at the Hong Kong Polytechnic University. The effectiveness of these activities was investigated using questionnaires and interviews to explore students' attitudes and approaches to learning. Results showed that the activities used helped foster the development of independent learning skills and the ability to apply knowledge. They also affected the quality of student learning by shaping the way they studied and meeting desired learning outcomes.

Still another study (Gravoso, Pasa, Labra, \& Mori, 2008), revealed positive effects of learner-centered methodologies on the overall quality learning. Video documentaries were used to ask students to explore problems associated with farmers. The students' learning outcomes and experiences were compared to a group of students who studied the same topics in a teacher-centered learning environment. The student-centered groups' understanding of the problems was found to be consistently higher than the control group. The results also showed that the learner-centered environment tended to engage students in the construction of knowledge, while those in the control group exhibited more knowledge absorption without much student participation in the formation of that knowledge. It was concluded that technology can change and improve the quality of learning outcomes if designed to support knowledge construction in a learner-centered learning environment.

\section{Context of the Problem}

Traditionally, teaching the courses in the teacher education program depends on lectures, readings, presentations, doing term papers, etc. Some of the faculty members adopt a task-based method. Others are teaching about the learner-centered methodology: its techniques, principles, and its applications in schools. However, it was rarely utilized systematically in classes. The purpose of this study was to investigate the effectiveness of adopting a learner-centered method to the teacher preparation program at SQU. The current study sought to answer the following questions: what is the effectiveness of a learner-centered course on teaching methodology at SQU? More specifically:

1) What are the features of an ELT Methods Course that might reflect the principles and techniques of the learner-centered methodology?

2) What is the effect of the course on the achievement of the students?

3) What are the students' perceptions with regard to:

Published by SCHOLINK INC. 
- Usefulness of the course,

- Interest in the course,

- Usefulness of the Moodle components, and the applicability of the principles of learner-centered techniques in Omani schools.

\section{Participants}

Seventy students participated in the current study in which a one-group pre-, post-test design was used. Thus, the subjects constituted a tactic sample.

Features of the-Learner Centered Course Seward Corporation and the English Unit Faculty cooperated in making this course a reality. It incorporated (see Table 1) 9 topics including 68 objectives. The course was mainly learner-centered in that the students are asked to do readings, watch video clips and take quizzes before coming to class. In the class, the instructors monitored required tasks, guided post task discussions, and guided students as they reflected on each of these components.

Topics of the Learner-Centered (henceforth: LC) Methods Course included: Task-based teaching, Learner characteristics, Assessment, Speaking, Writing, Grammar, Skill integration, Humanistic approaches, and Active learning. The aforementioned objectives, (68 in total) were subsumed by these topics. The course was based on the following principles:

1) Promoting mutual respect between students and teacher (e.g., using forms of politeness, discussing rules and procedures with students);

2) Fostering independent thinking (e.g., accepting innovative and creative answers, asking higher order questions instead of recall ones);

3) Encouraging students to share ideas and opinions through asking open questions;

4) Creating a stimulating classroom environment;

5) Teaching according to students' abilities;

6) Teaching according to students' learning styles (i.e. the way students learn);

7) Using a variety of teaching techniques;

8) Engaging students in active learning (e.g., task-based; problem-based activities, group work);

9) Developing and conducting higher order thinking skills (e.g., application, analysis, synthesis, and evaluation);

10) Providing opportunities for reflection among students (e.g., what is the new thing you learned today? What is the hardest part/point in the lesson?);

11) Assessing learners according to the lesson objectives;

12) Involving family and community in the educational process;

13) Including parents as partners in their children's education.

\section{Moodle Components}

Moodle was chosen as the principal platform through which to deliver the course. Additionally, 
students interacted via weekly forums and Wikis, watched video clips, did readings and assignments, and took quizzes at their own pace. Finally, both the mid-term and final exams for this course were administered and graded via Moodle, as well.

The learning cycle included three stages: Before class, In class, and After class. Following is a brief description of them with an example of one of the topics (Skill Integration).

1) Before class stage:

This stage included few readings on integrating teaching the 4 language skills, a quiz from 5 to 10 objective questions on the readings via Moodle, a video clip for students to watch and complete forms based on the principles of student centered methodology (see above), and a forum by assigning a topic related to the course for free discussion.

2) In class stage:

This stage included a warm-up task: (e.g., Examples of skill separation in language teaching), a mini-lecture (e.g., reasons for skills separation) and other tasks after the mini lecture (e.g., manipulating task components for skill integration), and an end of class reflection which encouraged students to reflect on the topic by answering questions such as think about this question: "What new ideas came to you today that you want to be sure to implement into your future classroom?", "Jot down your thoughts and share them with your Wiki team". Also, the reflection focuses on self-assessment tasks. Example: "What was the muddiest point?"

3) After class stage:

At the end of every class the students are provided with the different wiki assignments that include summary notes of the topic discussed in the session and the different tasks to continue work on and upload in the Moodle. In addition, students prepare for the next topic (Before class stage).

\section{Research Tools}

Two research tools-an achievement test and a student feedback form-were developed to measure the effectiveness of the learner-centered method course in general and this learner-centered cycle in particular.

1). The achievement test

In order to ensure a high level of content validity, the items of the achievement test were based on the topics of the course and the objectives included in each topic as summarized in the following table. 
Table 1. Distribution of Test Items in the Topics of Methods 2 Course

\begin{tabular}{lll}
\hline \multicolumn{2}{l}{ Topic } & Items \\
\hline 1. & Task-based teaching & 6 \\
2. & Learner characteristics & 7 \\
3. & Assessment & 6 \\
4. & Speaking & 5 \\
5 & Writing & 6 \\
6. & Grammar & 5 \\
7. & Skill integration & 5 \\
8. & Humanistic approaches & 5 \\
9. & Active learning & 6 \\
\hline & Total number of items & 51 \\
\hline
\end{tabular}

\section{Validity and Reliability}

For establishing the face validity of the test, it was given to 4 faculty members. Who recommended wording changes in some items and the deletion of certain others. For establishing the reliability, this modified test was then administered to 15 students who were attending the Methods 2 Course in the Fall 2009. This, in turn, led to further modifications and/or the deletions of certain test items, thus strengthening the face validity of the instrument.

Student Feedback Form: The student feedback form is used to assess learner reactions to instruction, class activities, assignments and materials. The feedback form was administered in order to ascertain the following:

1) The usefulness of the topics included (10 items),

2) To what extent the activities interested course participants ( 1 item),

3) The usefulness of the Moodle components, e.g., the readings, video clips, weekly quizzes, discussion forums, Wikis, and additional reading resources (6 items),

4) Participant reaction to taking the mid-term and final exams via Moodle (1 item),

5) The applicability of the learner-centered principles and techniques in actual teaching ( 2 items),

6) The extent to which the students have improved their teaching and learning as an overall result of attending the learner-centered Methods course (1 item), 
7) Students' suggestions for adding to or dropping topics from the LC-oriented Methods Course (1 open-ended Q),

8) The difficulties/challenges students met throughout the LC-oriented Methods 2 Course (1 open-ended Q),

9) Students' suggestions for maximizing and improving the quality and effectiveness of the LC-oriented Methods Course (1 open-ended Q).

The final version of the feedback form, as shown in Appendix I, includes 21 closed-ended and three open-ended items.

\section{Procedure}

The Pre-Test:

In the second week of the Fall of 2009, the achievement test was administered to the three sections of project participants.

The Post-Test:

It was also applied to the same students one week before the end of the semester. Only 42 cases were valid for the final analysis. The other tool-the student feedback form-was administered only towards the end of the course. Sixty six feedback forms were returned and analyzed.

\section{Data Analysis \& Findings}

The achievement test

What is the effect of the learner-centered course on students' achievement?

Table 2. Means and Standard Deviations of the Pre-Post Test

\begin{tabular}{|c|c|c|c|c|}
\hline & & Number & Mean & Std. Deviation \\
\hline \multirow[t]{2}{*}{1.} & True/false Pre & 42 & 10.19 & 1.97 \\
\hline & True/false/Post & 42 & 10.52 & 1.88 \\
\hline \multirow[t]{2}{*}{2.} & Definitions/Pre & 42 & 1.78 & 1.47 \\
\hline & Definitions/ Post & 42 & 3.28 & 2.67 \\
\hline \multirow[t]{2}{*}{3.} & MCQs /Pre & 42 & 17.26 & 2.66 \\
\hline & MCQs/Post & 42 & 18.43 & 3.10 \\
\hline \multirow[t]{2}{*}{4.} & Total/Pre & 42 & 29.21 & 3.31 \\
\hline & Total/Post & 42 & 33.24 & 5.47 \\
\hline
\end{tabular}


Table 3. The $t$-Values of the Pre-Post Test

\begin{tabular}{|c|c|c|c|c|}
\hline & & $t$-value & df. & Sig. \\
\hline \multirow[t]{2}{*}{1.} & True/false Pre & 0.88 & 41 & .384 \\
\hline & True/false/Pos & & & \\
\hline \multirow[t]{2}{*}{2.} & Definitions/ Pre & 5.38 & 41 & .000 \\
\hline & Definitions/ $\mathrm{P}$ & & & \\
\hline \multirow[t]{2}{*}{3.} & MCQs /Pre & 2.14 & 41 & .039 \\
\hline & MCQs/Post & & & \\
\hline \multirow[t]{2}{*}{4.} & Total/Pre & 4.25 & 41 & .000 \\
\hline & Total/Post & & & \\
\hline
\end{tabular}

Table 4. Mean and Standard Deviation of Males and Females on the Pre-Post Test

\begin{tabular}{|c|c|c|c|c|}
\hline & & Number & Mean & Std. Deviation \\
\hline \multirow[t]{2}{*}{1.} & $\begin{array}{l}\text { Males/Pre-t } \\
\text { est }\end{array}$ & 13 & 30.69 & 4.13 \\
\hline & $\begin{array}{l}\text { Males/Post- } \\
\text { test }\end{array}$ & 13 & 32.62 & 6.01 \\
\hline \multirow[t]{2}{*}{2 , } & $\begin{array}{l}\text { Females/Pr } \\
\text { e-Test }\end{array}$ & 29 & 28.55 & 4.29 \\
\hline & $\begin{array}{l}\text { Females/Po } \\
\text { st-Test }\end{array}$ & 29 & 33.51 & 5.29 \\
\hline
\end{tabular}

Table 5. The $t$-Values between the Pre-Post Test according to Gender

\begin{tabular}{lllll}
\hline & t-value & df. & Sig. \\
\hline 1. & Males/Pre-test Total & 1.19 & 12 & .255 \\
& Males/Post-test Total & & \\
$2, \quad$ Females/Pre-Test Total & 4.34 & 28 & .000 \\
& Females/Post-Test Total & & \\
\hline
\end{tabular}




\section{Results of the Pre/Post-Test}

As shown from Tables 2-5, there is a statistically significant difference between the total marks of the pretest and the post test in favor of the latter. The female students' performance accounted for most of this difference, which, while statistically significant, it is, practically, quite small. This result can be attributed to the following: The pre-test was conducted after two weeks of the actual beginning of the course and the post test a week before the end of the course. The post test lost around $50 \%$ of the total marks because, two weeks before the end of the course, the subjects were told that the topics covered on the mid-term would not be covered on the final. What is most important is that the LC methodology focuses on the process, not the learning outcome(s). Despite these results, it was concluded that, in terms of achievement, the learner-centered method is quite effective. The final exam grades reported below (Table 6) clearly attest to this fact.

Table 6. Students' Grades in the Final Exam

\begin{tabular}{lll}
\hline Grades & No. & $\%$ \\
\hline As & 5 & 7.7 \\
Bs & 44 & 67.7 \\
Cs & 15 & 23.1 \\
Ds & 1 & 1.5 \\
Fs & - & - \\
Total & 65 & $100 \%$ \\
\hline
\end{tabular}

Results of the Student Feedback Form

The respondents were asked to select the topics they feel that they need not cover in Methods 2 course, suggest topics to be added, and what they think about the moodle component.

1) Topics the respondents agreed should be dropped are:

-Humanistic approaches: The respondents mentioned that they are not used and considered traditional and difficult to apply in real classrooms.

-Assessment: The respondents thought it is theoretical and covered in other courses and therefore, not important to be included in Methods 2.

-Learner characteristics: The respondents stated that they are already covered in Methods 1 (a previous course) and also covered in another psychology course. In addition, it is difficult to apply in real classes and only relates to LC schools.

2) Suggested topics to be added by the respondents with some reasons:

-Increasing instructional games. They are useful and interesting for young learners, 
-Problems at Omani schools. There are different problems (e.g., the low level of students),

-How to connect with the family? How to deal with parents and educate them about their child?

-Relating what they cover to teaching practice and microteaching because some things learnt are not applied or cannot be applied,

-More focus on real life tasks.

3)The Moodle components:

Advantages:

-Moodle is good because students can help each other,

-Moodle enhances students' computer abilities,

-The wikis and forums are beneficial,

-Moodle helps students to be independent,

-Discussion forums help to share ideas,

-Activities are good, especially analyzing tasks,

-Taking notes is a useful skill,

-The organization/set up of the Moodle components is very attractive and colorful,

-Mostly the readings and the course are useful.

Difficulties:

-Too much readings leads to focus on finishing not understanding,

-Useless additional resources. No one reads them,

-Too much work which makes it stressful and distracts from focus,

-The quizzes are useless and students copy from materials or from others without understanding,

-Weekly quizzes are too much,

-Readings done just to do the quiz,

-Wikis take much time to do. They are also difficult to manage among group members,

-The Internet is not available and so it is difficult to do assignments,

-Taking exams via Moodle adds to anxiety.

4) Difficulties/challenges students met throughout the course

The students stated that it is too much work, stressful and too many readings/materials, and difficult to apply in real class (e.g., group work-applying the tasks).

5) Suggestions by respondents for improving the quality of the Methods 2 Course:

-Make it reasonable in terms of the amount of readings. Focus should be on quality,

-A careful process of material selection is needed,

-Need to match what is studied to application,

-Focus more on Harmer textbook. It is useful and clear, focus on the non-internet articles,

-Minimize work on wikis and Moodle in general,

-Some tasks are not beneficial and need to be modified, 
-Develop forum discussions and videos. Example, forums should involve interaction/discussion among students, not only answering the posted questions. Also, provide some questions for the videos and encourage analysis,

-Reduce work on Moodle, no need for reflection questions, forum discussions and videos; one or two activities are enough,

-No need for quizzes and exams online,

-Assessment should be task-based as the course is, and not objective questions,

-Wikis should be more interesting and involve application and thinking.

\section{Conclusion \& Recommendations}

The current study shows some evidence that support the use of learner centered methodology which is similar to various previous studies (Sivan et al., 2000; Ahmaed \& Mahmood, 2010; Geisli, 2009; and Gravoso et al., 2008) that revealed positive effects of student centered methods on students' achievement and quality of learning. Despite the students' dissatisfaction about certain aspects of the course and in the light of the findings reported above, it can be concluded that the LC methodology project was effective for several reasons, as it 1) involved students in active learning processes and tasks, 2) minimized dependence on traditional lectures, 3) gave students more responsibility for their learning, 4) fostered team work and cooperative learning, and 5) manipulated technology and e-learning efficiently. Accordingly, it is recommended that the learner-centered Methodology be applied to the other courses of the teacher education program at SQU.

\section{Sustainability \& Follow-Up}

The faculty participants in this project have got much experience to do with the LC Methodology. However, they also concede the fact that there is still much to learn about LC methods. Currently, they are practicing more of what they have been preaching in this learner centered methodology. They have extended their experience to the other courses of the teacher education program, e.g. Methods 1 , Educational Curriculum, Teaching Practice $1 \& 2$, and a number of other Master's-level courses. In order to empower teaching and Learning, they further recognize that all stakeholders must take practical action in the following: 1) cultivating the LC culture in the pre-service and in-service teacher education program, 2) convincing SQU faculty and Ministry of Education teachers of the importance of the LC methodology, and 3) developing supplementary LC methodolgy tasks and activities for actual use in classrooms. In future, course textbooks and assessment procedures and instruments should be adapted to better reflect the LC methodology-oriented. 


\section{References}

Ahmed, Z., \& Mahmood, N. (2010). Effects of Cooperative Learning vs. Traditional Instruction on Prospective Teachers' Learning Experience and Achievement. Ankara University. Journal of Faculty of Educational Sciences, 4(1), 151-164.

Baeton, M. K. E., Struyven, K., \& Dochy, F. (2010). Using Student-Centered learning environment to stimulate deep approaches to learning: Factors encouraging or discouraging their effectiveness. Educational Research Review, 5(3), 243-260.

Bowel, C. C., \& Eison, J. A. (1991). Active Learning: Creating excitement in the classroom. ASHE.ERIC, Higher Education Reports ED 336049.

Bransford, J. D., Brown, A. L., \& Cocking, R. R. (Eds.). (1999). How People Learn: Brain, Mind, Experience, and School. Washington, DC: National Academy Press.

Cannon, R., \& Newble, D. (2000). A Handbook for teachers in universities and colleges (4th ed.). London: Kogan Page.

Duckworth, E. (1987). The Having of wonderful Ideas. Aladdin Papaerbacks.

Garfield, J. (1995). How students learn statistics. International Statistical Review, 63(1), 25-34.

Geisli, Y. (2009). The effect of student centered instructional approaches on student Success. Procedia Social and Behavioral Sciences, 1, 469-473.

Gravoso, R. S., \& Pasa, A. E. (2008). Design and Use of Instructional Materials for Student-Centered Learning: A Case in Learning Ecological Concepts. The Asia-Pacific Education Researcher, 17(1), $109-120$

Hannafin, M. J., Hannafin, K. M., Land, S. M., \& Oliver, K. (1997). Grounded Practice and the Design of constructivist learning environment. Educational Technology Research and Development, 45(3), 101-117.

O’Sullivan, M. (2004). The reconceptualisation of learner-centred approaches: A Namibian case study. International Journal of Educational Development, 24, 585-602.

Piaget, J., \& Inhelder, B. (1969). The Psychology of the child. New York: Basic Books.

Prince, M. (2004). Does Active learning work? A review of the Research Journal of Engineering Education, 93(3), 223-231.

Sablonniere, R., Taylor, D. M., Perozzo, C., \& Sadykova, N. (2009). Reconceptualizing relative deprivation in the context of dramatic social change: The challenge confronting people of Kyrgyzstan. European Journal of Social Psychology, 39, 325-345.

Sablonniere, R., Taylor, M., \& Sadykova, N. (2009). Challenges of applying a student-centered approach to learning in the context of education in Kyrgyzstan. International Journal of Educational Development, 29(8), 628-634.

Schuh, K. L. (2004) Learner-centered principles in teacher-centered practices? Teaching and Teacher Education, 20, 833-846.

Sivan, A., Leung, R. W., Woon, C., \& Kember, D. (2000). An Implementation of Active Learning and its 
Effect on the Quality of Student Learning. Innovations in Education and Teaching International, 37(4), 381-389.

Vavrus, F. (2009). The cultural politics of constructivism pedagogies: Teacher Education Reform in the United Republic of Tanzania. International Journal of Educational Development, 29(3), 303-311.

\section{Appendix I}

\section{Student Feedback Form for collecting data from students about the Methods 2 course}

Dear students

The following are the various components and teaching procedures incorporated in Methods 2 course.

Please, read the items and circle the responses you most agree with. (Please, don't write your name)

\begin{tabular}{|l|l|l|l|l|l|}
\hline $\begin{array}{l}\text { I. On this scale, please rate the } \\
\text { usefulness of the following topics } \\
\text { you covered in Methods 2. }\end{array}$ & Very useful & Mostly useful & Somewhat useful & Totally useless \\
\hline 1 & Task-based learning & 4 & 3 & 2 & 1 \\
\hline 2 & Learner characteristics & 4 & 3 & 2 & 1 \\
\hline 3 & Assessment & 4 & 3 & 2 & 1 \\
\hline 4 & Speaking Part 1 \& Part 2 & 4 & 3 & 2 & 1 \\
\hline 5 & Writing Part 1\& 2 & 4 & 3 & 2 & 1 \\
\hline 6 & Grammar Part 1 \& Part 2 & 4 & 3 & 2 & 1 \\
\hline 7 & Integrating skills & 4 & 3 & 2 & 1 \\
\hline 8 & Humanistic approaches & 4 & 3 & 2 & 1 \\
\hline
\end{tabular}

9. Suggest adding or deleting the topics you feel that you need/need not to cover in Methods 2. Please, mention the reason(s) for that.

a.

b.

c.

Reasons: 
10. Overall, how interesting did you find the tasks and activities you conduced in class while covering the topics above?

\begin{tabular}{|l|l|l|l|}
\hline Very & & & Totally \\
interesting & Interesting & Boring & boring \\
\hline
\end{tabular}

\begin{tabular}{|c|c|c|c|c|c|}
\hline \multicolumn{2}{|r|}{$\begin{array}{l}\text { II. What do you think about the } \\
\text { Moodle components? }\end{array}$} & \multirow{2}{*}{\begin{tabular}{|l|} 
Very \\
useful
\end{tabular}} & \multirow{2}{*}{$\begin{array}{l}\text { Mostly useful } \\
3\end{array}$} & \multirow{2}{*}{\begin{tabular}{|l} 
Somewhat useful \\
2
\end{tabular}} & \multirow{2}{*}{$\begin{array}{l}\text { Totally useless } \\
1\end{array}$} \\
\hline 1 & $\begin{array}{l}\text { The readings for class } \\
\text { preparation every week }\end{array}$ & & & & \\
\hline 1 & $\begin{array}{l}\text { Watching the video clips and } \\
\text { completing assignments }\end{array}$ & 4 & 3 & 2 & 1 \\
\hline 1 & Doing the weekly quizzes & 4 & 3 & 2 & 1 \\
\hline 1 & $\begin{array}{l}\text { Moodle tasks after class follow } \\
\text { up, e.g. the Discussion Forums }\end{array}$ & 4 & 3 & 2 & 1 \\
\hline 1 & $\begin{array}{l}\text { Moodle tasks after class follow } \\
\text { up, e.g. the reflection Wikis }\end{array}$ & 4 & 3 & 2 & 1 \\
\hline 1 & The additional resources & 4 & 3 & 2 & 1 \\
\hline \multicolumn{6}{|c|}{ 17. Comments: } \\
\hline
\end{tabular}




\begin{tabular}{|c|c|c|c|c|c|}
\hline 18. & $\begin{array}{l}\text { What do you think about } \\
\text { taking the mid and final exams } \\
\text { via the Moodle? }\end{array}$ & Very relevant & Relevant & $\begin{array}{l}\text { Somewhat } \\
\text { relevant }\end{array}$ & Irrelevant \\
\hline 19. & $\begin{array}{l}\text { To what extent can you apply } \\
\text { the principles and techniques } \\
\text { you learned in Methods } 2 \text { to } \\
\text { Microteaching? }\end{array}$ & $\begin{array}{l}\text { To a large } \\
\text { extent }\end{array}$ & $\begin{array}{l}\text { To some } \\
\text { extent }\end{array}$ & $\begin{array}{l}\text { To a little } \\
\text { extent }\end{array}$ & Not at all \\
\hline 20. & $\begin{array}{l}\text { To what extent can you apply } \\
\text { the principles and techniques } \\
\text { you learned in Methods } 2 \text { to } \\
\text { teaching practice classrooms? }\end{array}$ & $\begin{array}{l}\text { To a large } \\
\text { extent }\end{array}$ & $\begin{array}{l}\text { To some } \\
\text { extent }\end{array}$ & $\begin{array}{l}\text { To a little } \\
\text { extent }\end{array}$ & Not at all \\
\hline 21. & $\begin{array}{l}\text { Overall, have you met any dif } \\
\ldots \ldots \ldots \ldots \ldots \ldots \\
\ldots \ldots \ldots \ldots \ldots \\
\ldots \ldots \ldots \ldots \ldots\end{array}$ & $\begin{array}{l}\text { iculties/challen } \\
\ldots \ldots \ldots \ldots \ldots \ldots \\
\ldots \ldots \ldots \ldots \ldots \ldots \\
\ldots \ldots \ldots \ldots \ldots \ldots \\
\ldots \ldots \ldots \ldots \ldots \ldots\end{array}$ & $\begin{array}{l}\text { es throughout } \\
\ldots \ldots \ldots \ldots \ldots \ldots \\
\ldots \ldots \ldots \ldots \ldots \ldots \\
\ldots \ldots \ldots \ldots \ldots \ldots \\
\ldots \ldots \ldots \ldots \ldots \ldots\end{array}$ & $\begin{array}{c}\text { iis course? Plea } \\
\ldots \ldots \ldots \ldots \ldots \ldots \\
\ldots \ldots \ldots \ldots \ldots \ldots \\
\ldots \ldots \ldots \ldots \ldots \ldots \\
\ldots \ldots \ldots \ldots \ldots \ldots\end{array}$ & $\begin{array}{l}\text { se, specify. } \\
\ldots \ldots \ldots \ldots \ldots \\
\ldots \ldots \ldots \ldots \ldots \\
\ldots \ldots \ldots \ldots\end{array}$ \\
\hline 22. & What are your suggestions fol & improving the & uality of the $M$ & thods 2 course & \\
\hline
\end{tabular}

Thanks for cooperation. 